\title{
Determination of stress strain state in pipe subjected to internal pressure at plane strain condition under elasto plastic loading
}

\author{
D. Vaičiulis*, A. Bražènas** \\ *Kaunas University of Technology,Daukanto 12, 35212 Panevěžys, Lithuania, E-mail: dainius.vaiciulis@ktu.lt \\ **Kaunas University of Technology, Daukanto 12, 35212 Panevėžys, Lithuania, E-mail: algis.brazenas@ktu.lt
}

crossref http://dx.doi.org/10.5755/j01.mech.17.4.559

\section{Introduction}

The buried pipes are frequently analyzed by using numerical methods [1-3]. In numerical model of a buried pipe the plane strain condition is used.

Analytical method for the determination of stress state in a pipe subjected to internal pressure at plane strain condition and elasto plastic loading for incompressible material (Poisson's ratio $v=0.5$ ) is presented in work [4]. In this case tensile curve of material in elasto plastic loaded zone is approximated by linear function. Radial and circumference stresses in work [4] are determined by the dependencies ${ }^{1}$ :

$$
\left.\begin{array}{c}
\sigma_{r p} \\
\sigma_{\theta p}
\end{array}\right\}=\frac{\sigma_{p l}}{\sqrt{3}}\left[\left(1-\frac{E_{1}}{E}\right)\left(2 \ln \frac{r}{r_{p}} \mp 1\right)+\frac{r_{p}^{2}}{r_{e x}^{2}} \mp \frac{E_{1}}{E} \frac{r_{p}^{2}}{r^{2}}\right]
$$
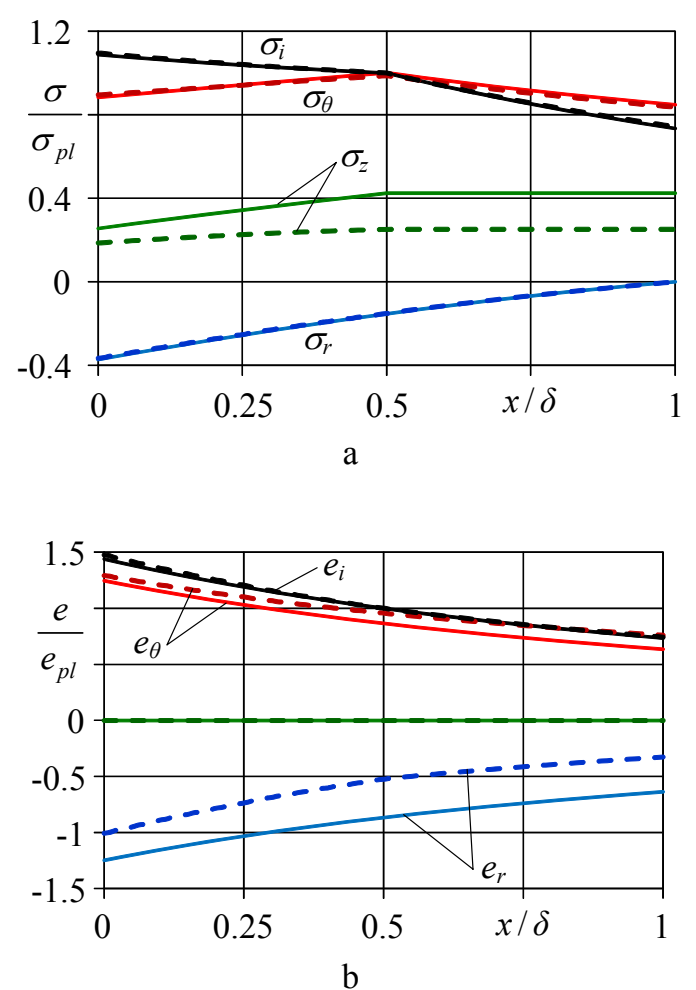

Fig. 1 Distribution of stress (a) and strain (b) components in the thickness of pipe wall $\delta$ when $E_{1} / E=0.2$ and $r_{p}=\left(r_{i n}+r_{e t}\right) / 2:(-)$ obtained analytically when $v=0.5 ;(---)$ determined by FEA when $v=0.3$ and $v^{*}<0.5\left(v^{*}\right.$ is effective Poisson's ratio)

\footnotetext{
${ }^{1}$ lower index $p$ denotes values at elasto plastic loaded zone lower index $e$ denotes values at elastic loaded zone
}

$$
\left.\begin{array}{l}
\sigma_{r e} \\
\sigma_{\theta e}
\end{array}\right\}=\frac{\sigma_{p l}}{\sqrt{3}} \frac{r_{p}^{2}}{r_{e x}^{2}}\left(1 \mp \frac{r_{e x}^{2}}{r^{2}}\right)
$$

where $\sigma_{p l}$ is limit of elasticity; $r_{p}$ is maximum pipe radius of elasto plastically deformed zone; $r_{e x}$ is external radius of the pipe; $E$ is modulus of elasticity; $E_{1}$ is hardening modulus of the material in elasto plastic zone.

The stress strain state components calculated analytically when $v=0.5$ [4] and determined by FEA (finite element analysis) when $v=0.3$ are shown in Fig. 1. In this case stress strain components mostly differ at external surface of the pipe: $\sigma_{r}-2 \%, \sigma_{\theta}-1.5 \%, \sigma_{z}-70 \%, \sigma_{i}-1.5 \%$, $e_{r}-85 \%, e_{\theta}-15 \%$ and $e_{i}-3 \%$. Therefore, the method presented in work [4] is inapplicable for the investigation of radial stiffness of a pipe under elasto plastic loading.

The analytical method for stress strain state determination in homogeneous pipe subjected to elasto plastic loading at plane strain condition with taking into account compressibility of the material $(v \leq 0.5)$ is presented in this paper.

\section{Determination of stress strain state components in homogeneous pipe at elasto plastic loading}

The solution is made by using the relative parameters: $\rho=r / r_{i n}, s=\delta / r_{i n}, \rho_{i n}=1, \rho_{e x}=r_{e x} / r_{i n}=1+s$, $\xi=x / \delta(0 \leq \xi \leq 1), \rho=\left(r_{i n}+x\right) / r_{i n}=1+\xi s$ (Fig. 2).

The load is determined by using relative coordinate $\xi_{p}$ which denotes the maximum value of elasto plastically deformed zone.

Stress intensity at plane strain condition

$$
\sigma_{i}=\sqrt{\sigma_{r}^{2}+\sigma_{\theta}^{2}+\sigma_{z}^{2}-\sigma_{r} \sigma_{\theta}-\sigma_{r} \sigma_{z}-\sigma_{\theta} \sigma_{z}}
$$

By estimating that $\sigma_{z}=v\left(\sigma_{r}+\sigma_{\theta}\right)$

$$
\sigma_{i}=\sqrt{\left(\sigma_{\theta}-\sigma_{r}\right)^{2}-v(1-v)\left(\sigma_{\theta}+\sigma_{r}\right)^{2}+\sigma_{r} \sigma_{\theta}}
$$

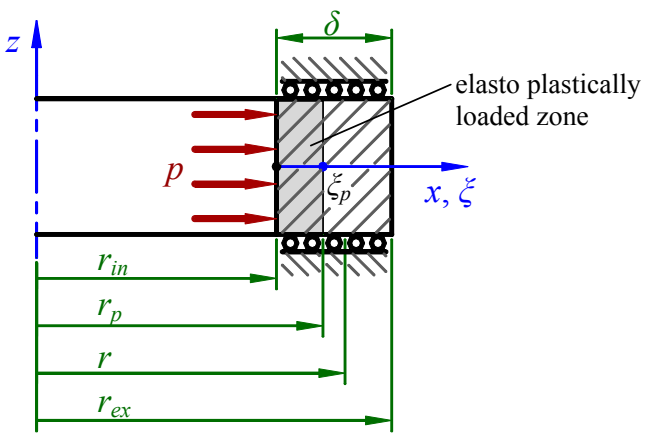

Fig. 2 Scheme of homogeneous pipe subjected to internal pressure at plane strain condition 
Strain intensity at plane strain condition

$$
e_{i}=\frac{1}{1+v} \sqrt{e_{r}^{2}+e_{\theta}^{2}-e_{r} e_{\theta}}
$$

In elasto plastically loaded zone in Eqs. (4) and (5) instead of $v$ must be used effective Poisson's ratio

$$
v^{*}=0.5-(0.5-v) E^{\prime} / E
$$

where $E^{\prime}=\sigma_{i p} / e_{i p}$ is secant modulus of material tensile curve.

In elastic loaded zone radial and circumference stresses may be determined by Lame's equations [5] ${ }^{2}$

$$
\left.\begin{array}{l}
\sigma_{r}^{L}(\xi) \\
\sigma_{\theta}^{L}(\xi)
\end{array}\right\}=\frac{p_{e}}{s(2+s)}\left[1 \mp\left(\frac{1+s}{1+\xi s}\right)^{2}\right]
$$

where $p_{e}$ is inner pressure when it is assumed that the material is deformed only elastically (Eq. 10).

By taking into account Eqs. (4) and (7) the stress intensity at elastic loading

$$
\sigma_{i e}(\xi)=\frac{p_{e}}{s(2+s)} \sqrt{3\left(\frac{1+s}{1+\xi s}\right)^{4}+(1-2 v)^{2}}
$$

Elasto plastic strains in the pipe appear when

$$
p>p_{\text {e } \max }=\frac{\sigma_{p l} s(2+s)}{\sqrt{3(1+s)^{4}+(1-2 v)^{2}}}
$$

It is assumed that in elastically deformed zone, when $p>p_{\text {e max }}\left(\xi_{p}>0\right)$, behavior of material is the same as in elastic loading. Therefore in elastically deformed zone for determination of stresses the fictitious inner pressure

$$
p_{e f}=\frac{\sigma_{p l} s(2+s)}{\sqrt{3\left(\frac{1+s}{1+\xi_{p} s}\right)^{4}+(1-2 v)^{2}}}
$$

is used, i.e. in Eqs. (7) and (8) when $\xi \geq \xi_{p}$ instead of $p_{e}$ the value $p_{e f}$ must be used.

In elasto plastically loaded zone strain intensity $e_{i p}$ is calculated from the presumption, that the potential energy for elastic and elasto plastic loading is the same [6] (Fig. 3)

$$
\frac{1}{2} e_{i e} \sigma_{i e}=\frac{1}{2} e_{e} \sigma_{p l}+\int_{e_{e}}^{e_{i p}} \sigma_{i p} \mathrm{~d} e_{i p}
$$

From Eq. (11) follows that when tension curve of the material in elasto plastically loaded zone is approximated by power function

$$
e_{i p}(\xi)=\frac{\sigma_{p l}}{E}\left\{1+\frac{\left(m_{0}+1\right)\left[\sigma_{i e}^{2}(\xi)-\sigma_{p l}^{2}\right]}{2 \sigma_{p l}^{2}}\right\}^{\frac{1}{m_{0}+1}}
$$

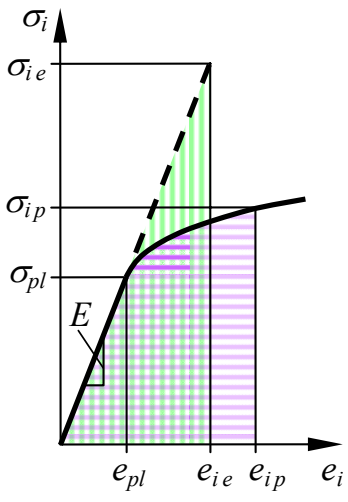

a

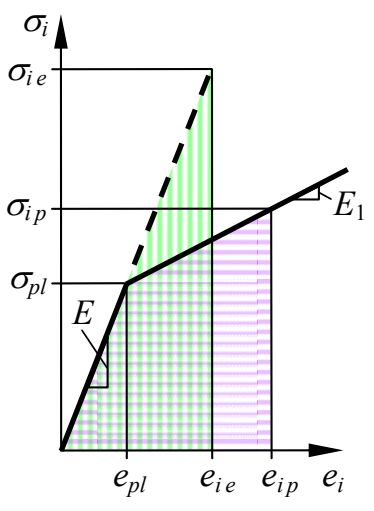

$\mathrm{b}$
Fig. 3 Scheme for determination of strain intensity $e_{i p}$ in elasto plastically loaded zone when tension curve is approximated by: $a$ - power function; $b$ - linear function

and when approximated linearly -

$$
e_{i p}(\xi)=\frac{\sigma_{p l}}{E}\left\{1-\frac{E}{E_{1}}\left[1-\sqrt{1+\frac{E_{1}}{E}\left(\frac{\sigma_{i e}^{2}(\xi)}{\sigma_{p l}^{2}}-1\right)}\right]\right\}
$$

where $\xi \leq \xi_{p}$; in this case in expression of $\sigma_{i e}(\xi)$, i.e. in Eq. (8) instead of $v$ must be used $v^{*} ; m_{0}$ is power index of material hardening in elasto plastic zone.

At elasto plastic loading stress intensity

$$
\sigma_{i p}(\xi)=\sigma_{p l}\left(\frac{e_{i p}(\xi)}{e_{p l}}\right)^{m_{0}}
$$

or

$$
\sigma_{i p}(\xi)=\sigma_{p l}+\left[e_{i p}(\xi)-e_{p l}\right] E_{1}
$$

When material of the pipe is deformed elasto plastically and $\sigma_{i e}\left(\xi_{p}\right)=\sigma_{p l}$, the inner pressure can be calculated form the assumption that mean elastic circumference stress expressed in term of $p$ is equal to the mean circumference stress, when elasto plastic loading appears (Fig. 4), i.e.

$$
\int_{0}^{1} \sigma_{\theta}(\xi, p) d \xi=\int_{0}^{\xi_{p}} \sigma_{\theta p}(\xi) d \xi+\int_{\xi_{p}}^{1} \sigma_{\theta}^{L}(\xi) d \xi
$$

where $\sigma_{\theta}(\xi, p)$ is circumference stress calculated form Eq. (7) by substituting $p$ instead of $p_{e}$.

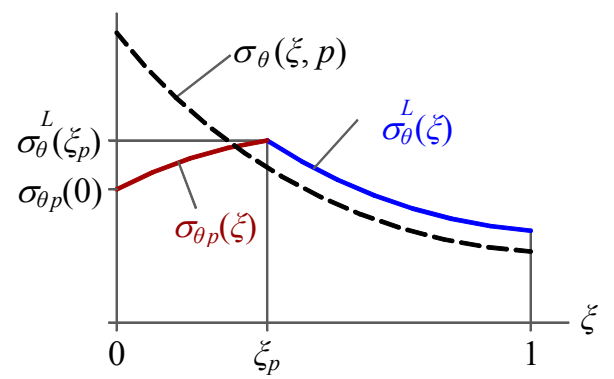

Fig. 4 Scheme for determination of $p$

\footnotetext{
${ }^{2}$ upper index $L$ denote Lame's equation
} 
Determination of $\int_{0}^{\xi_{p}} \sigma_{\theta p}(\xi) d \xi$ is complicated. Therefore, in this work it is accepted that

$$
\int_{0}^{\xi_{p}} \sigma_{\theta p}(\xi) \mathrm{d} \xi \approx \frac{1}{2} \xi_{p}\left[\sigma_{\theta p}(0)+\sigma_{\theta}^{L}\left(\xi_{p}\right)\right]
$$

where $\sigma_{\theta p}(0)$ is calculated by approaching method form Eq. (20), when $\sigma_{r p}(0)=-p$.

Then Eq. (16) can be written

$p=\frac{s \xi_{p}}{2}\left[\sigma_{\theta p}(0)+\sigma_{\theta}^{L}\left(\xi_{p}\right)\right]+p_{e f} \frac{\left(1-\xi_{p}\right)\left(2+s+\xi_{p} s\right)}{(2+s)\left(1+\xi_{p} s\right)}$

The values of radial stresses $\sigma_{r}$ in two points of elasto plastically loaded zone are known: $\sigma_{r p}(0)=-p$ and $\sigma_{r p}\left(\xi_{p}\right)=\sigma_{r}^{L}\left(\xi_{p}\right)$. In other points of elasto plastically loaded zone stress $\sigma_{r}$ is calculated by assuming that it is distributed linearly

$$
\sigma_{r p}(\xi)=\sigma_{r}^{L}\left(\xi_{p}\right) \frac{\xi}{\xi_{p}}-p \frac{\xi_{p}-\xi}{\xi_{p}}
$$

When $\sigma_{i p}(\xi)$ and $\sigma_{r p}(\xi)$ are known the circumference stress at elasto plastic loaded zone can be calculated from Eq. (4)

$$
\begin{aligned}
& \sigma_{\theta p}(\xi)=\frac{\sigma_{r p}(\xi)\left(1+2 C_{v}\right)}{2\left(1-C_{v}\right)}+ \\
& +\sqrt{\frac{3 \sigma_{r p}^{2}(\xi)\left(4 C_{v}-1\right)}{4\left(1-C_{v}\right)^{2}}+\frac{\sigma_{i p}^{2}(\xi)}{\left(1-C_{v}\right)}}
\end{aligned}
$$

where $C_{v}=v^{*}\left(1-v^{*}\right)$.

For stress strain state determination in any point of the pipe at elasto plastic loading, when $\xi_{p}$ is known, the inner pressure $p$ must be determined in this way:

- $p_{e}$ from Eq. (10) is calculated;

- $e_{i p}(0), \sigma_{i p}(0)$ and $v^{*}$ by approaching method from Eqs. (12), (14) or (13), (15) and (6) are calculated. For the determination of $\sigma_{i e}(0)$ by Eq. (8) instead of $v$ must be used $v^{*}$. In first approaching can be assumed $v^{*}=v$;
- $p$ and $\sigma_{\theta p}(0)$ are determined by approaching method from Eqs. (18), (20) and taking into account $\sigma_{r p}(0)=-p$. In first approaching can be assumed $p=p_{e f}\left(1-0.2 \xi_{p}\right)$.

The stresses state components in elasto plastically loaded zone $\left(\xi \leq \xi_{p}\right)$ are determined in this way:

- $e_{i p}(\xi), \sigma_{i p}(\xi)$ and $v^{*}$ by approaching method from Eqs. (12), (14) or (13), (15) and (6) are determined. In expression of $\sigma_{i e}(\xi)$, i.e. in Eq. (8) instead of $v$ must be used $v^{*}$. In first approaching can be assumed $v^{*}=v$;

- $\sigma_{r}(\xi), \sigma_{\theta}(\xi)$ and $\sigma_{i}(\xi)$ stresses are calculated from Eqs. (19), (20) and (4).

Stresses in elastically loaded zone $\left(\xi \geq \xi_{p}\right)$ are calculated form Eqs. (7) and (8) by using $p_{e f}$ instead of $p_{e}$.

Strains $e_{r}$ and $e_{\theta}$ are calculated by generalized Hooke's law. In elasto plastically loaded zone the $v^{*}$ and $E^{\prime}$ must be used instead of $v$ and $E$.

\section{Stresses and strains investigations at elasto plastic loading}

Dependence of stress strain state components distribution on $\xi_{p}$ are shown in Fig. 5 and 6. In elasto plastically deformed zone with increasing of $\xi$ stresses $\sigma_{r}, \sigma_{\theta}$, $\sigma_{z}$ increase while strains and stress intensity $\sigma_{i}$-decreases.

Comparison of stress strain components obtained analytically and determined by FEA is presented in Table. The disagreement increases with increasing elasto plastically deformed zone. When elasto plastically deformed zone increases up to $2 / 3$ of wall thickness the disagreement for stresses is up to $4.5 \%$ and for strains $-5.5 \%$. When elasto plastically deformed zone does not exceed mean radius of the pipe wall $\left(\xi_{p} \leq 0.5\right)$ disagreement for the stresses is up to $3.0 \%$ and for strains $-1.5 \%$.

When the pipe is loaded elasto plastically a negligible increase of inner pressure caused extensive increase of elasto plastically deformed zone (see Fig. 6). For example, for the pipe with $s=0.4$, in order to reach plastic zone from $\xi_{p}=0.5$ to $\xi_{p}=1.0$ the inner pressure must increase only 1.106 times and for the pipe with $s=0.2-1.054$ times. Analogous results were obtained in work [7]. When elasto plastically deformed zone reaches the external surface of the pipe wall the stability of the structure may be loosed. Therefore, in design of pipelines it is recommended that under instantaneous overloading the elasto plastically deformed zone should not exceed the mean radius of the pipe wall.
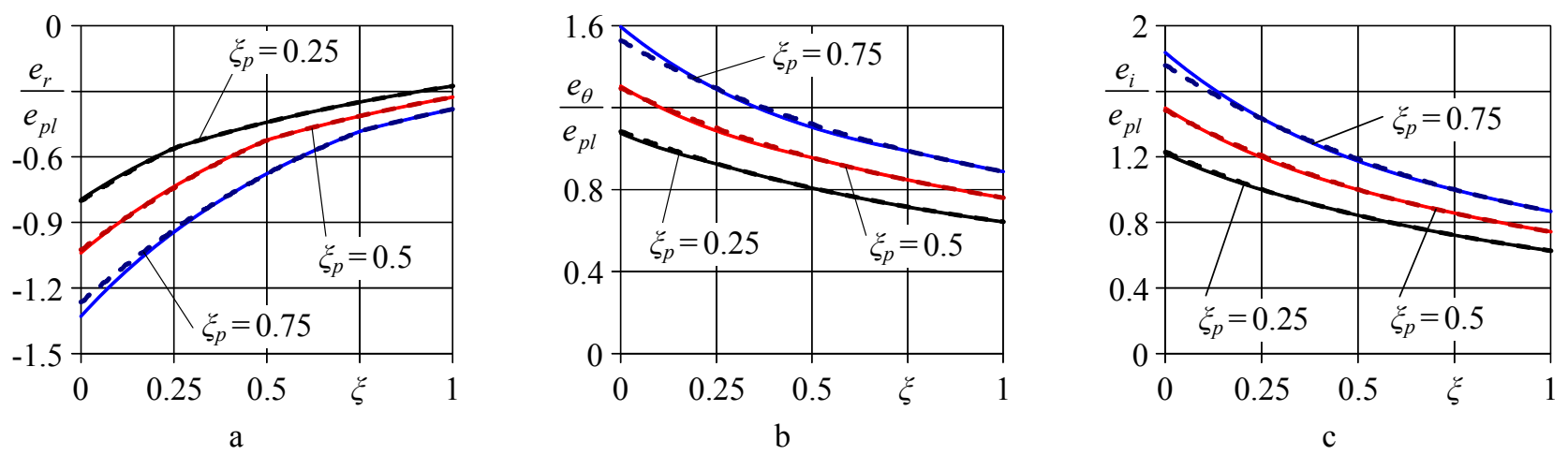

Fig. 5 Dependences of strains distribution on $\xi_{p}$ in the thickness of pipe wall determined analytically $\left(-\frac{-}{-}\right.$ and by FEA $(---)$ when $s=0.4, v=0.3$ and $m_{0}=0.15$ : a - radial strain $e_{r} ; \mathrm{b}-$ circumference strain $e_{\theta} ; \mathrm{c}-$ strain intensity $e_{i}$ 

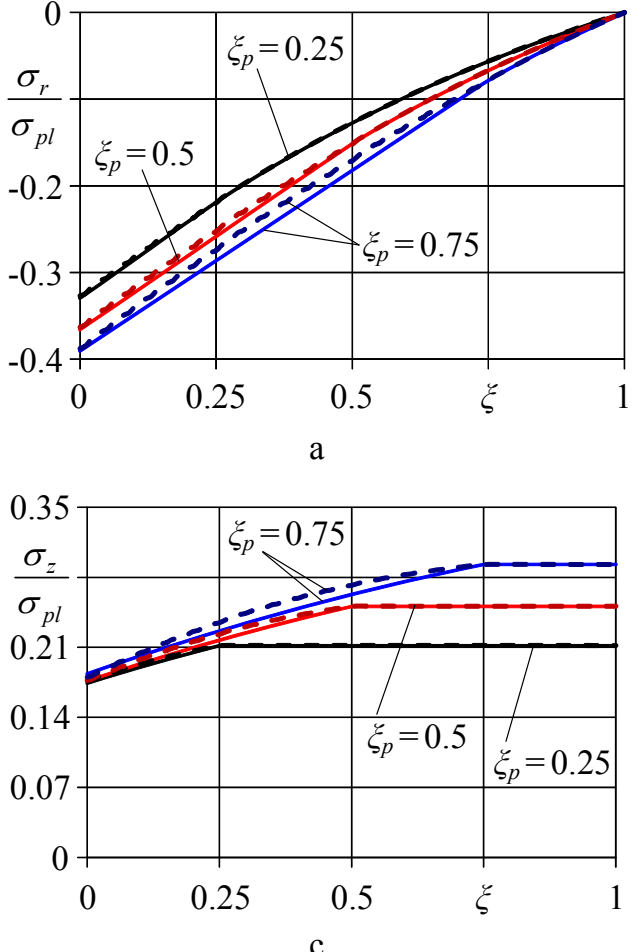
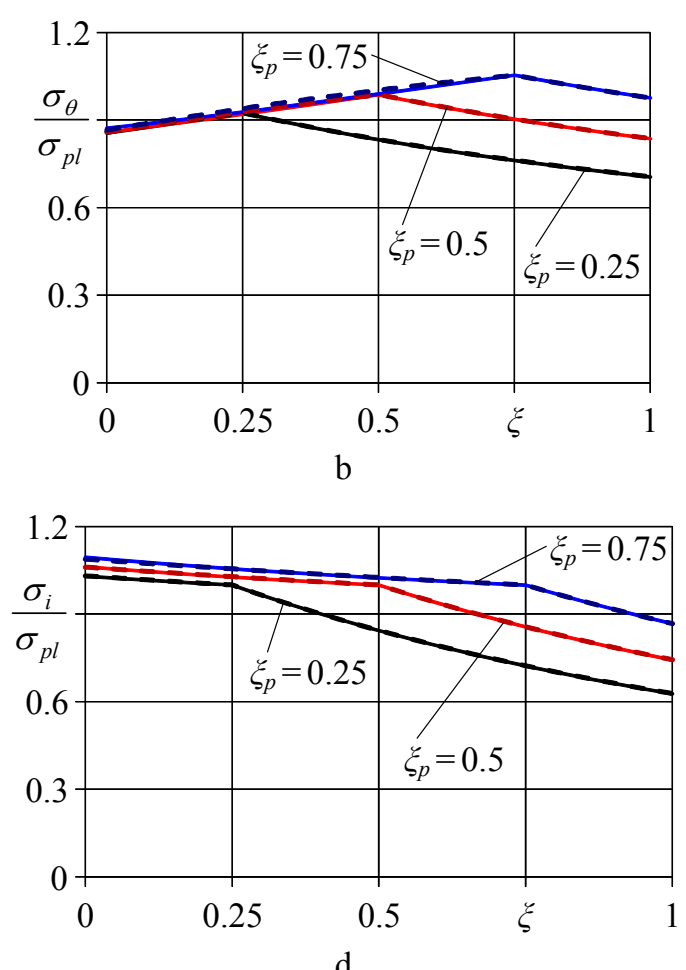

Fig. 6 Dependences of stresses distribution on $\xi_{p}$ in the thickness of pipe wall determined analytically $\left(-\frac{-}{-}\right.$ and by FEA $(---)$ when $s=0.4, v=0.3$ and $m_{0}=0.15$ : a - radial stress $\sigma_{r} ; \mathrm{b}$ - circumference stress $\sigma_{\theta} ; \mathrm{c}-$ axial stress $\sigma_{z}$; $\mathrm{d}-$ stress intensity $\sigma_{i}$

Table

Comparison of stress strain state components obtained by the method presented in this works and determined by FEA

\begin{tabular}{|c|c|c|c|c|c|c|c|c|c|c|c|c|c|c|}
\hline \multirow[t]{2}{*}{$\xi$} & \multicolumn{4}{|c|}{$\begin{array}{c}\text { Analytical } \\
\text { (FEA) }\end{array}$} & \multicolumn{4}{|c|}{ Disagreement, $\%$} & \multicolumn{3}{|c|}{$\begin{array}{c}\text { Analytical } \\
\text { (FEA) }\end{array}$} & \multicolumn{3}{|c|}{ Disagreement, $\%$} \\
\hline & $\sigma_{r} / \sigma_{p l}$ & $\sigma_{\theta} / \sigma_{p l}$ & $\sigma_{z} / \sigma_{p l}$ & $\sigma_{i} / \sigma_{p l}$ & $\sigma_{r} / \sigma_{p l}$ & $\sigma_{\theta} / \sigma_{p l}$ & $\sigma_{z} / \sigma_{p l}$ & $\sigma_{i} / \sigma_{p l}$ & $e_{r} / e_{p l}$ & $e_{\theta} / e_{p l}$ & $e_{i} / e_{p l}$ & $e_{r} / e_{p l}$ & $e_{\theta} / e_{p l}$ & $e_{i} / e_{p l}$ \\
\hline \multicolumn{15}{|c|}{$\xi_{p}=0.25$} \\
\hline 0.00 & \begin{tabular}{|c|}
-0.330 \\
$(-0.327)$ \\
\end{tabular} & $\begin{array}{c}0.856 \\
(0.860) \\
\end{array}$ & \begin{tabular}{|c|}
0.174 \\
$(0.177)$ \\
\end{tabular} & $\begin{array}{c}1.030 \\
(1.031) \\
\end{array}$ & 0.92 & 0.47 & 1.69 & 0.10 & $\begin{array}{c}-0.795 \\
(-0.800) \\
\end{array}$ & $\begin{array}{c}1.075 \\
(1.084) \\
\end{array}$ & $\begin{array}{c}1.221 \\
(1.229)\end{array}$ & 0.63 & 0.83 & 0.65 \\
\hline 0.125 & $\begin{array}{c}-0.274 \\
(-0.275)\end{array}$ & $\begin{array}{c}0.889 \\
(0.891)\end{array}$ & $\begin{array}{c}0.194 \\
(0.195)\end{array}$ & $\begin{array}{c}1.014 \\
(1.016) \\
\end{array}$ & 0.36 & 0.22 & 0.51 & 0.20 & $\begin{array}{c}-0.667 \\
(-0.673)\end{array}$ & $\begin{array}{c}0.990 \\
(1.000)\end{array}$ & $\begin{array}{c}1.098 \\
(1.108)\end{array}$ & 0.89 & 1.00 & 0.90 \\
\hline 0.25 & $\begin{array}{c}-0.219 \\
(-0.220)\end{array}$ & $\begin{array}{c}0.924 \\
(0.924)\end{array}$ & $\begin{array}{c}0.211 \\
(0.212)\end{array}$ & $\begin{array}{c}1.000 \\
(1.001)\end{array}$ & 0.45 & 0.00 & 0.47 & 0.10 & $\begin{array}{c}-0.560 \\
(-0.563)\end{array}$ & $\begin{array}{c}0.927 \\
(0.929)\end{array}$ & $\begin{array}{c}1.000 \\
(1.003)\end{array}$ & 0.53 & 0.22 & 0.30 \\
\hline 1.00 & \begin{tabular}{|c|}
0.000 \\
$(0.000)$
\end{tabular} & $\begin{array}{c}0.706 \\
(0.707)\end{array}$ & $\begin{array}{c}0.212 \\
(0.212)\end{array}$ & \begin{tabular}{|c|}
0.627 \\
$(0.628)$
\end{tabular} & 0.00 & 0.14 & 0.00 & 0.16 & \begin{tabular}{|c|}
-0.275 \\
$(-0.276)$
\end{tabular} & $\begin{array}{c}0.642 \\
(0.643)\end{array}$ & $\begin{array}{c}0.627 \\
(0.628)\end{array}$ & 0.36 & 0.16 & 0.16 \\
\hline \multicolumn{15}{|c|}{$\xi_{p}=0.50$} \\
\hline 0.00 & \begin{tabular}{|c|}
-0.366 \\
$(-0.363)$ \\
\end{tabular} & $\begin{array}{c}0.858 \\
(0.859)\end{array}$ & \begin{tabular}{|c|}
0.176 \\
$(0.177)$ \\
\end{tabular} & \begin{tabular}{|c|}
1.063 \\
$(1.061)$ \\
\end{tabular} & 0.83 & 0.12 & 0.56 & 0.19 & $\begin{array}{c}-1.039 \\
(-1.024) \\
\end{array}$ & $\begin{array}{c}1.306 \\
(1.294) \\
\end{array}$ & $\begin{array}{c}1.498 \\
(1.483) \\
\end{array}$ & 1.46 & 0.93 & 1.01 \\
\hline 0.25 & $\begin{array}{c}-0.258 \\
(-0.253) \\
\end{array}$ & $\begin{array}{c}0.920 \\
(0.928) \\
\end{array}$ & $\begin{array}{c}0.217 \\
(0.223) \\
\end{array}$ & $\begin{array}{c}1.027 \\
(1.029) \\
\end{array}$ & 1.98 & 0.86 & 2.69 & 0.19 & $\begin{array}{c}-0.736 \\
(-0.744)\end{array}$ & $\begin{array}{c}1.087 \\
(1.103)\end{array}$ & $\begin{array}{c}1.196 \\
(1.210)\end{array}$ & 1.08 & 1.45 & 1.16 \\
\hline 0.50 & $\begin{array}{c}-0.151 \\
(-0.152)\end{array}$ & $\begin{array}{c}0.987 \\
(0.987) \\
\end{array}$ & $\begin{array}{c}0.251 \\
(0.251) \\
\end{array}$ & $\begin{array}{c}1.000 \\
(1.001)\end{array}$ & 0.66 & 0.00 & 0.00 & 0.10 & $\begin{array}{c}-0.523 \\
(-0.525)\end{array}$ & $\begin{array}{c}0.957 \\
(0.959)\end{array}$ & $\begin{array}{c}1.000 \\
(1.002)\end{array}$ & 0.38 & 0.21 & 0.20 \\
\hline 1.00 & \begin{tabular}{|c|}
0.000 \\
$(0.000)$ \\
\end{tabular} & $\begin{array}{c}0.836 \\
(0.837) \\
\end{array}$ & $\begin{array}{c}0.251 \\
(0.251) \\
\end{array}$ & $\begin{array}{c}0.743 \\
(0.744) \\
\end{array}$ & 0.00 & 0.12 & 0.00 & 0.13 & $\begin{array}{c}-0.326 \\
(-0.326)\end{array}$ & $\begin{array}{c}0.761 \\
(0.761) \\
\end{array}$ & $\begin{array}{c}0.743 \\
(0.743)\end{array}$ & 0.00 & 0.00 & 0.00 \\
\hline \multicolumn{15}{|c|}{$\xi_{p}=0.75$} \\
\hline 0.00 & \begin{tabular}{|c|}
-0.390 \\
$(-0.388)$
\end{tabular} & $\begin{array}{c}0.873 \\
(0.867)\end{array}$ & \begin{tabular}{|c|}
0.184 \\
$(0.180)$
\end{tabular} & $\begin{array}{c}1.096 \\
(1.088)\end{array}$ & 0.52 & 0.69 & 2.22 & 0.74 & $\begin{array}{c}-1.329 \\
(-1.263)\end{array}$ & $\begin{array}{c}1.596 \\
(1.527)\end{array}$ & $\begin{array}{c}1.837 \\
(1.759)\end{array}$ & 5.23 & 4.52 & 4.43 \\
\hline 0.375 & $\begin{array}{c}-0.234 \\
(-0.224)\end{array}$ & $\begin{array}{c}0.958 \\
(0.971) \\
\end{array}$ & $\begin{array}{c}0.245 \\
(0.255) \\
\end{array}$ & $\begin{array}{c}1.039 \\
(1.041) \\
\end{array}$ & 4.46 & 1.34 & 3.92 & 0.19 & $\begin{array}{c}-0.799 \\
(-0.807) \\
\end{array}$ & $\begin{array}{c}1.186 \\
(1.207)\end{array}$ & $\begin{array}{c}1.292 \\
(1.309)\end{array}$ & 0.99 & 1.74 & 1.30 \\
\hline 0.75 & $\begin{array}{c}-0.078 \\
(-0.079) \\
\end{array}$ & $\begin{array}{c}1.054 \\
(1.054) \\
\end{array}$ & $\begin{array}{c}0.293 \\
(0.293) \\
\end{array}$ & $\begin{array}{c}1.000 \\
(1.000) \\
\end{array}$ & 1.27 & 0.00 & 0.00 & 0.00 & $\begin{array}{c}-0.482 \\
(-0.485)\end{array}$ & $\begin{array}{c}0.990 \\
(0.992)\end{array}$ & $\begin{array}{c}1.000 \\
(1.002)\end{array}$ & 0.62 & 0.20 & 0.20 \\
\hline 1.00 & $\begin{array}{c}0.000 \\
(0.000)\end{array}$ & $\begin{array}{c}0.976 \\
(0.976) \\
\end{array}$ & $\begin{array}{c}0.293 \\
(0.293) \\
\end{array}$ & $\begin{array}{c}0.868 \\
(0.868) \\
\end{array}$ & 0.00 & 0.00 & 0.00 & 0.00 & $\begin{array}{c}-0.381 \\
(-0.381)\end{array}$ & $\begin{array}{c}0.889 \\
(0.889)\end{array}$ & $\begin{array}{c}0.868 \\
(0.868)\end{array}$ & 0.00 & 0.00 & 0.00 \\
\hline
\end{tabular}




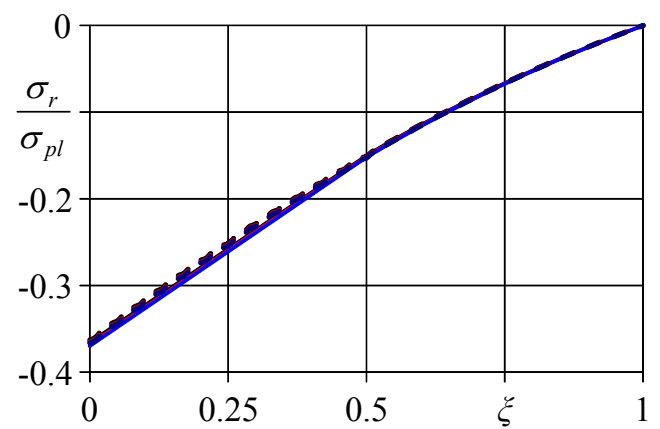

a

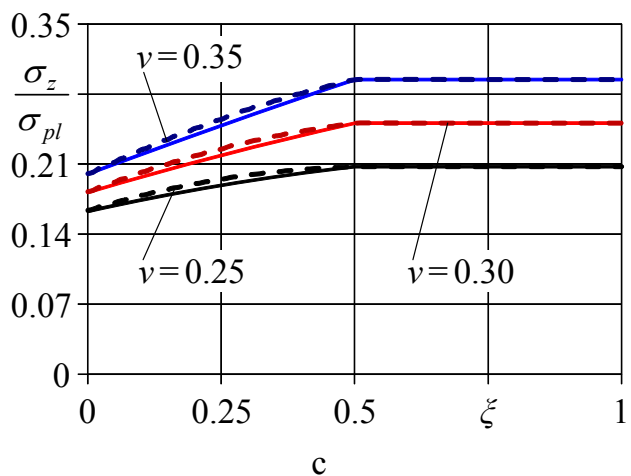

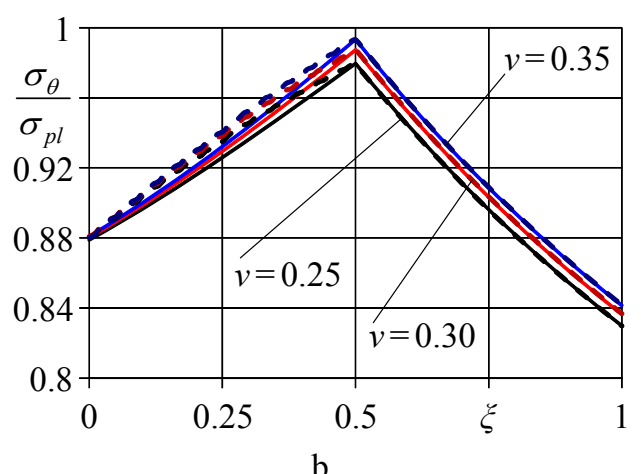

b

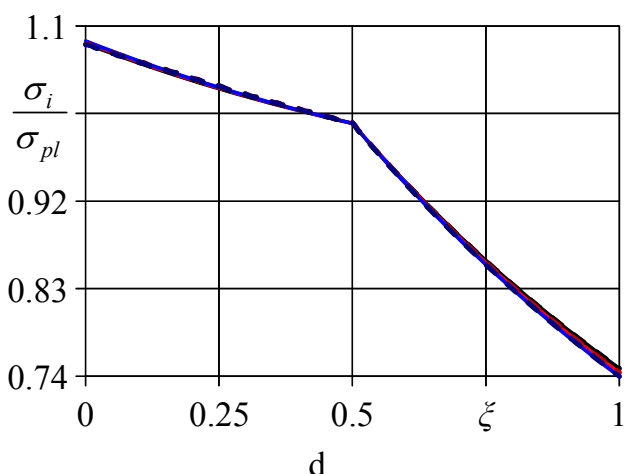

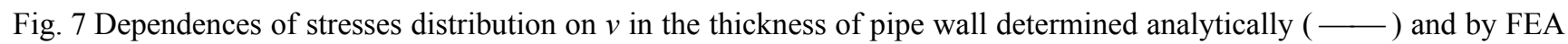
$(---)$ when $s=0.4, \xi_{p}=0.5$ and $m_{0}=0.2$ : a - radial stress $\sigma_{r} ; \mathrm{b}-$ circumference stress $\sigma_{\theta} ; \mathrm{c}-$ axial stress $\sigma_{z}$; $\mathrm{d}$ - stress intensity $\sigma_{i}$

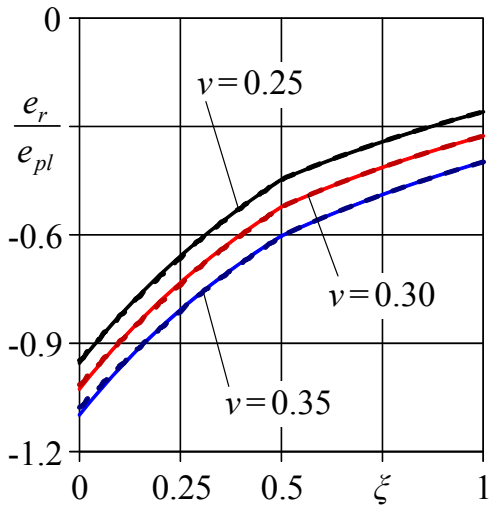

a

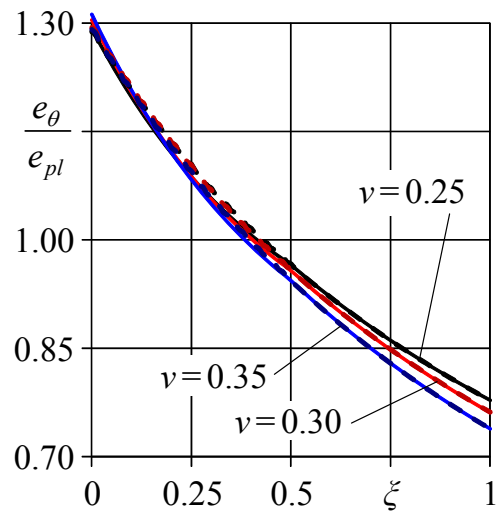

b

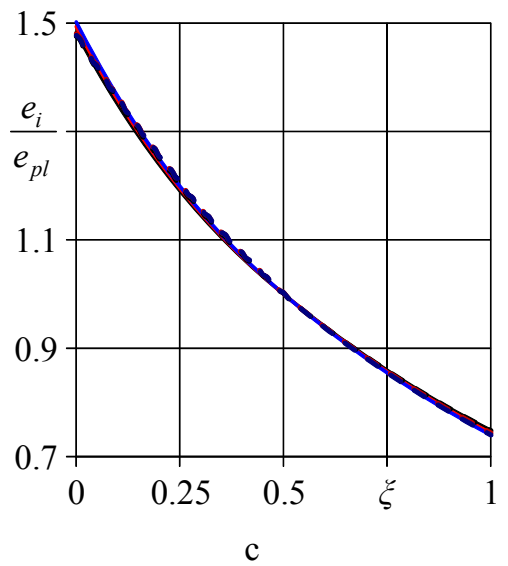

Fig. 8 Dependences of strains distribution on $v$ in the thickness of pipe wall determined analytically $\left(-\frac{-}{-}\right)$ and by FEA
$(---)$ when $s=0.4, \xi_{p}=0.5$ and $m_{0}=0.2$ : a - radial strain $e_{r} ; \mathrm{b}-$ circumference strain $e_{\theta} ; \mathrm{c}-$ strain intensity $e_{i}$

Dependence of stress strain state components distribution on Poison's ratio $v$ is shown in Figs. 7 and 8. With increasing $v$ the axial stress $\sigma_{z}$ and radial strain $e_{r}$ increases, circumference stress $\sigma_{\theta}$ increases negligibly, circumference strain $e_{\theta}$ at inner radius of the pipe negligibly increases and at external radius - decreases. Radial stress $\sigma_{r}$, intensities $\sigma_{i}$ and $e_{i}$ practically does not depend on $v$. In this case disagreement between stress state components values obtained by the method presented in this paper and determined by FEA does not exceed $3.0 \%$ and strains $-2.0 \%$.

Under elasto plastic loading and cyclic characteristics of the material are related $[6,8]$. Therefore, the dependencies presented in this work enable to increase accuracy of the buried pipelines durability determination.

\section{Conclusions}

Dependencies for stresses and strains determination in homogeneous pipe subjected to internal pressure at elasto plastic loading, plane strain condition and taking into account compressibility of the pipe material are presented in this paper. By FEA it is proved that accuracy of these dependencies is quite acceptable.

In design of pipelines it is recommended that under instantaneous overloading the elasto plastically deformed zone does not exceed the mean radius of pipe wall $\left(\xi_{p} \leq 0.5\right)$.

With increasing Poison's ratio $v$ the axial stress $\sigma_{z}$ and radial strain $e_{r}$ increases, circumference stress $\sigma_{\theta}$ increases negligibly, circumference strain $e_{\theta}$ at inner radius 
of pipe negligibly increases and at external radius - decreases. Radial stress $\sigma_{r}$, stress intensity $\sigma_{i}$ and strain intensity $e_{i}$ practically does not depend on $v$ (for example, when $v$ changes by $40 \%$, the $\sigma_{r}$ changes only by $1.4 \%$, $\sigma_{i}-1.1 \%$ and $\left.e_{i}-1.3 \%\right)$.

\section{References}

1. di Prisco, C.; Galli, A. 2006. Soil-pipe interaction under monotonic and cyclic loads: experimental and numerical modelling. Proceedings of the First Euro Mediterranean Symposium in Advances on Geomaterials and Structures. Hammamet, Tunisia, 3-5 May 2006. 755761.

2. Gondle, R.; Siriwardane, H. 2008. Finite element modelling of long term performance of buried pipes. The $12^{\text {th }}$ international conference "International Association for Computer Method and Advances in Geomechanics". Goa, India, 1-6 October, 2008. 3993-4000.

3. Sabbah-Yazdi, S.R.; Alkhamis, M.T.; Esmaili, M.; Mastorakis, N.E. 2008. Finite volume analysis of towdimensional strain in a thick pipe with internal fluid pressure. International journal of mathematical models and methods in applied sciences. Issue 1, Volume 2. 162-167.

4. Aleksandrov, A.V.; Potapov V.D. 1990. The Principles of Elasticity and Plasticity. Moscow: Vysshaja shkola. 400p. (in Russian).

5. Feodosjev, V. 1970. Strength of Materials. Moscow: Nauka. 544 p. (in Russian).

6. Bražènas, A. 2002. Strength and Low Cycle Fatigue Life of Mechanically Heterogeneous Butt Welded Joints. Monograph. Kaunas: Technologija. 284p.

7. Bražènas, A.; Kaminskas, V. 2009. Stress strain state and strength of pipe subjected to internal pressure under static elastic plastic loading. Proc. 14th Int. Conf. Mechanika - 2009. Kaunas: Technologija. 63-68.
D. Vaičiulis, A. Bražènas

\section{VAMZDŽIO, VEIKIAMO VIDINIO SLĖGIO, ITEMPIŲ \\ IR DEFORMACIJŲ BŪVIO NUSTATYMAS ESANT \\ PLOKŠČIAJAI DEFORMACIJAI IR TAMPRIAI PLASTINIAM APKROVIMUI}

R e z i u m è

Darbe nagrinejjamas vienalyčio vamzdžio, veikiamo vidinio slègio, įtempiai ir deformacijos esant plokščiajam deformacijų būviui. Šis būvis susidaro požeminiuose vamzdynuose. Baigtinių elementų metodu patvirtinta, kad darbe siūloma ittempių ir deformacijų nustatymo metodika yra gana tiksli. Darbe taip pat pateiktos itempiu ir deformacijų būvio komponenčių pasiskirstymo priklausomybès nuo vidinio slègio dydžio ir Puasono koeficiento.

D. Vaičiulis, A. Bražėnas

\section{DETERMINATION OF STRESS STRAIN STATE IN PIPE SUBJECTED TO INTERNAL PRESSURE AT PLANE STRAIN CONDITION UNDER ELASTO PLASTIC LOADING}

S u m m a r y

The stress strain state of homogeneous pipe subjected to internal pressure at elasto plastic loading and plane strain condition is analyzed. The plane strain condition appears in buried pipelines. By using FEA it is proved that the accuracy of presented methodic for determination of stresses and strains is quite acceptable. Dependences of stress strain state components distribution on value of inner pressure and Poison's ratio are also presented.

Received 18 February, 2011 Accepted June 30, 2011 